\title{
DISCURSIVE CREATION TECHNIQUE OF ENGLISH TO INDONESIAN SUbTItLE IN HaRRY POTTER: THE CHAMBER OF SECRETS MOVIE
}

\author{
Lilik Istiqomah, Medy Erawati, Sonya Lianti Suparno \\ IAIN Surakarta \\ mdcorp100@gmail.com, medyerawati@gmail.com, sonyalianti9@gmail.com
}

\begin{abstract}
The purpose of this paper is to analyze the used of discursive creation technique of English to Indonesian subtitle in Harry Potter: The Chamber of Secrets movie. This research is descriptive qualitative method. Data of this research are utterances or sentences in subtitle movie of bilingual edition, both English and Indonesian. While, the source of data of this research is Harry Potter: The Chamber of Secrets movie. The researchers only used one data source; it was document. In analyzing the data, the researchers used comparison method to compare between the SL and TL that were analyzed. The result of this research shows that discursive analysis divided into three catogories of language unit, they are word $23 \%$, phrase $20 \%$, and sentence $57 \%$. Therefore, it can be concluded that the translator has many errors in the sentence translated because he chooses the easy sentence in order to make viewer understand the subtitle.
\end{abstract}

Keywords: translation technique, discursive creation, subtitle, harry potter

\section{INTRODUCTION}

Translation has always been a central part of communication. Consequently, Translation studies (TS), as a field of research, has developed over the last two decades during which screen translation has slowly emerged as a new area (O'Connell, 2007). Translation fields have become more colorful and diversity, such as film subtitle translation, business translation and advertising translation. Especially in the film subtitle translation. In nowadays, film become the part of being human life and aims to entertaiment, not only local film but also foreign film become the favorite of our society. How to make audience understand film easier, it is that film translation is of great significance to us.

Subtitling is a form of literary translation that used in audio-visual which aims to make audience understood with the film especially film from other language and countries. Baker \& Hochel in Ghaemi \& Benyamin (2010: 39) stated Subtitling is visual, involving the superimposition of a written text onto the screen. Subtitling may be describe as a translation practice that consists of rendering in writing, usually at the bottom of the screen, the translation into a target language of the original dialogue exchanges uttered by different speakers, as well as all other verbal information that appears written on screen (letters, banners, inserts) or is transmitted aurally in the soundtrack (song lyrics, voice off) (Diaz Cintas, 2012: 274).

The process of movie subtitle translation is not merely a conversion between two languages, but a process of transmission and transplant in which cultural exchange is included (Cui-ping, 2015: 28). The translator is not only translated the original intention of the source text completely as possible, but the cultural information as well. To make the audience understand with film, subtitles should be as short as possible. A viewer has absolutely no knowledge of the source language only has the visuals, sound effects and subtitles to help them understand with the film. To make the audience enjoying film, we should serve subtitles as short as possible to give viewer chance to comparing with images or visuals in film.

Foreign film which is mostly spoken in English like Harry Potter Series: The Chamber of Secrets written by J.K Rowling is originally made in UK and US, distributed by Warner Bros. Pictures had a background culture of Britain surely which should be translated into Indonesian in a clear, accurate and readable translation product to be understood by the Indonesian audiences. But the problems are why the translator reduce the translation in some part of subtitle and does the translator transplant the cultural information as well to make audience easly understand the film?

These studies covered the techniques proposed by Molina and Albir and over all stated that some techniques were not appropriate to be implemented into some extends for some terms. The researchers try to analyze one of the translation techniques called discursive creation to know why translator made dissappear some of subtitle text and change the context. Masero (2014: 318) states that every text and its utterances are part of a specific context. These utterances and their context can be more or less alien to target culture and will show more or less translation problems that can make the process of translation 
more or less complicated. Thus, the discursive creation here were categorized into three categories language unit they are word, phrase and sentence.

\section{MATERIALS AND METHOD}

Translation technique as procedures to analyse and calssify how translation equivalence works. One of the translation techniques that the researchers used in this movie is discursive creation. Molina \& Albir (2002: 510) defines discursive creation as a technique to establish a temporary equivalence that is totally unpredictable out of context. This is an operation in the cognitive process of translating by which a non-lexical equivalence is established that only works in context (Delisle, 1993) in Molina Albir (2002: 505). It means that discursive creation makes the TT absolutely different from the SL. The differences that not only the meaning, but also the point of view, subject, character and situation.

Another opinion is that discursive creation refers to equivalents that would only work in that specific situation (Cortes, 2016). In other words, discursive creation is only used in specific and cultural situations. May be in one culture the ST can not be translated literally, so the translator used discursve creation to make the audience interested in the film or novel. Discursive creation many used in the title of film, newspaper and novel, example the title of newspaper "The General Spoke" translated into "Sang Jenderal Angkat Bicara".

O'Connel (2007: 169) defines subtitling as 'suplementing the original voice soundtrack by adding written text to the screen'. So, the main role for subtitling is to facilitate an access for the foreign viewers on audio visual product in foreign language. As with any other type of translation, subtitle are expected to provide a semantically adequate of the original dialogue that they must at the same time the visual and the written text. The problem arises when people on screen speak language which can't be translated because of any different language cultural or the speaker speak to quickly so its used reduction which sometimes out of context. This is why discursive creation is arguably the core strategy in use by subtitlers and the subject of this detailed research.

The study of this article uses descriptive qualitative method. The writer only collected, classified, analyzed the data and then drew conclusion and verification. The writer describes the facts concerning the object of the research, then analyzes about translation analysis in qualitative way. The object of this research is discursive creation technique of translation English to Indonesian subtitle of Harry Potter 2 "The Camber of the Secret" movie. Data of this research are utterances or sentences in the script movie which involves two different languages both the SL (English) and the TL (Indonesian).

Meanwhile, the source of the data of this research is Harry Potter 2 "The Camber of The Secret" movie. In collecting the data, the writer uses content analysis which uses written document or subtitle movie. In analyzing the data, the writer uses the following steps: 1) Reading the Subtitle Movie. 2) Collecting the Primary Data, 3) Coding the Primary Data, 4) Classifying the Primary Data, 5) Collecting the Secondary Data, 6) Analysis the Secondary Data, 7) Displaying and Drawing Conclusion (Fitria, 2015: 6).

\section{RESULTS AND DISCUSSION}

The dominance of sentence language category, which is 28 (57\%) of the total 49 data of discursive creation. Therefore, here the writer tries to shows an analysis of the data above categories when comparing the SL in English into Indonesian as TL in the discursive creation technique of the movie subtitle. It can easily understand the error word or sentence that is used in the subtitle. The analysis is as follows:

\subsection{WORD}

(Datum 10)

ST: Now, now Draco, play nicely.

TT: Sudah sudah Draco, yang sopan dong.

Literally, in Cambridge Advanced Learner's Dictionary (3rd Edition) now means at the present time. The translator translated now as sudah, while the Indonesian word of sudah means as of a certain point in time or past. The word now can be used as an emphasis in conversation. The better translated of 'now, now' is "nah, nah". 


\subsection{Phrase}

In phrase, the researchers found three phrases in the analysis of subtitle film Harry Potter: The Chamber of secret there were:

\subsubsection{VERB PHRASE}

(Datum 19)

ST: If you're talking about Malfoy-. Of course. You heard him!

TT: Kalau kamu pikir itu Malfoy... Iya lah. kamu dengar dia kan?

As we know a verb phrase is a phrase which consists of main verb and auxiliary verb. The main verb of the example is talking with are which the auxiliary. According to Cambridge Advanced Learner's Dictionary (3rd Edition) talking from the word talk which means to speak to someone or to say words aloud. The translator translated the phrase you're talking as kamu pikir, exactly the Indonesian word kamu pikir means you're thinking. The better translated of "if you're talking about Malfoy" is "kalau kamu berbicara tentang Malfoy".

\subsubsection{NOUN PHRASE}

(Datum 9)

ST: Nice big smile, Harry. Together you and I rate the front page!

TT: Senyum yang lebar, Harry. Kita akan masuk halaman muka.

It is clear that the utterance is phrase, especially noun phrase. Premodifier "adjective" nice and big with the head "noun" is smile. The adjective nice means menyenangkan and big means besar/lebar, the nice big smile here translated into senyum yang lebar by the translator with reducing the meaning of one word. If it is translated literally, nice big smile will be "senyum lebar yang menyenangkan".

\subsubsection{ADVERB PHRASE}

\section{(Datum 17)}

ST: Innocent until proven guilty, Severus. My cat has been Petrified.

TT: Tak bersalah sampai ada bukti, Severus. Kucingku dibekukan!

The translator translated the phrase until proven guilty as sampai ada bukti with guilty is the adverb of manner which means dengan bersalah. The word proven is from prove that depends on CAD meant to show that something is true. The better translated of until proven guilty is "sampai terbukti bersalah".

\subsection{Sentence}

(Datum 42)

ST: I'm afraid we feel you have rather lost your touch

TT: Menurut kami, anda sudah kehilangan kendali

The translator translated the sentence above is out of context, the TT is very different with the ST. Based on CAD, afraid means feeling fear or feeling worry about the possible results of a particular situation. I'm afraid in the subtitle translated into menurut kami, even in Indonesian word of menurut kami means according to or based on or depend on. Then, the word touch in CAD means an ability to do things in the stated, especially in positive way, rather than kendali that in Indonesian word means control. The better translated of "I'm afraid we feel you have rather lost your touch" is "saya khawatir, kami merasa anda telah kehilangan kemampuan anda".

There were 1505 data, yet after doing some analysis 62 data were obtained including discursive creation technique. After some deep analysis there were, finally 49 data were taken and analyzed. This data reduction was done because there was repeating information in some data. From 49 data that were taken from the English to Indonesian subtitle, it was divided into three categories of language unit which were sentence, phrase and word. The data can be seen in the following table:

Table Data Findings of Discursive Creation Categorized Language Unit

\begin{tabular}{|l|l|l|l|l|}
\hline No. & Form of source Text & Frequency & Percentage & Number of Data \\
\hline 1. & Word & 10 & $23 \%$ & $3,10,11,12,16,26,27,29$, \\
\hline
\end{tabular}




\begin{tabular}{|c|c|c|c|c|}
\hline & & & & 30,37 \\
\hline 2. & Phrase & 11 & $20 \%$ & $\begin{array}{l}1,6,8,9,17,19,21,24,28 \\
35,43\end{array}$ \\
\hline 3. & Sentence & 28 & $57 \%$ & $\begin{array}{l}2,4,5,7,13,14,15,18,20, \\
22,23,25,31,32,33,34,36 \\
38,39,40,41,42,44,45,46, \\
47,48,49\end{array}$ \\
\hline \multicolumn{2}{|c|}{ Total } & 49 & $100 \%$ & \\
\hline
\end{tabular}

\section{CONCLUSION}

From the explanation of findings above, it showed that discursive creation technique divided into three categories of language unit, they were word, phrase, and sentence. In phrase, the researchers found noun phrase, verb phrase and adverb phrase in the data. From the data, the researchers found 28 Datum or $57 \%$ subtitles which used discursive creation technique that had a different meaning in sentence.

Thus, the translator translateed the subtitle different from the source text in order to make viewers understand of the film because there was any different culture. The translator just changing the subtitle with simple words based on their feelings and sometime untranslate the subtitle because there is no one comparison which suitable with Indonesian language. Better, the translator looked for the most suitable language without out of context in order to give good subtitle.

The writer recognizes that the aspects discussed in this study are still minor from overall aspects that can be assessed in relation to movie subtitling analysis and semi-professional research in field of translation. Therefore, the writers hope other researchers can improve this study, for instance by analyzing translation technique of Harry Potter movie in another serries with different translation technique or discussing translation quality of Harry Potter: The Chamber of Secrets by involving rater as secondary data.

\section{REFERENCES}

Cortez, Luisa Olmeldo. [2016]. On Translation Techniques or Impossible Translations. Retrieved December 18, 2018, from https://bookmachine.org/2016/12/02/on-translation-techniques-orimpossible-translations/

Cui-ping, Han and Ni Xue-li. 2015. "On the Subtitle Translation of Mirror Mirror from Relevance Theory" in American Research Journal of English and Literature 2378-9026, vol 1, issue 3, June (2015): 26- 33

Diaz-Cintas, Jorge. 2012. Subtitling from: The Routledge Handbook of Translation Studies Routledge. Accessed on 01 December 2018

Diaz-Cintas. Jorge. 2012. Subtitling: Theory, Practice, Reasearch. University College London. Accessed on 01 December 2018

Fitria, Tira Nur. 2015. Translation Technique of English to Indonesian Subtitle in Doraemon "Stand by Me" Movie. Universitas Muhammadiyah Surakarta

Ghaemi, Farid and Janin Benyamin. 2010. Strategies Used in the Translation of Interlingual Subtitling. Journal of English Studies 1(1), 39-49, Winter 2010. Islamic Azad University

Masero, Ana Tamayo. 2014. "Translating Slang for Dubbing: A Descriptive Case Study of Jackie Brown (English-Spanish)", Linguae-Revista de la Sociedad Espanola de Modernas, 1 (2014), 315-340

Molina, Lucia \& Amparo H. Albir. 2002. "Translation Techniques Revisited: A Dynamic and Functionalist Approach", Meta: Translators' Jurnal, vol. 47, no. 4, 2002, p. 498-512.

O’Connell, E. 2007. Screen Translation. In P. Kuhiwczak and K. Littau (Eds.), A Companion to Translation Studies (pp. 120-133). Toronto: Multilingual Matters Ltd.

Roks, Berber. 2014. A Study in Subtitles: Translation Universals in Sherlock. Leiden University

Shuttleworth, M \& Mira Cowie. 1997. Dictionary of Translation Studies. London: St. Jerome. Publishing Company. 
